DedikasiMU (Journal of Community Service)

Volume 3, Nomor 4, Desember 2021

\title{
UPAYA PENURUNAN PREVALENSI PENYEBARAN COVID-19 DI KELURAH KEBONSARI TUBAN
}

\author{
Zufra Inayah $^{1}$, Nugrahadi Dwi Pasca Budiono ${ }^{2}$, Kirana Warita Megowati ${ }^{3}$, Ana Dwi Silvana ${ }^{4}$, \\ Ernawati $^{5}$, Sukaris ${ }^{6}$, Andi Rahmad Rahim ${ }^{7}$
}

\author{
${ }^{1,2}$ Dosen Program Studi Kesehatan Masyarakat, Universitas Muhammadiyah Gresik \\ ${ }^{3,4}$ Mahasiswa Program Studi Kesehatan Masyarakat, Universitas Muhammadiyah Gresik \\ ${ }^{5}$ Dosen Ilmu Keprawatan, Universitas Muhammadiyah Gresik \\ ${ }^{6}$ Dosen Program Studi Manajemen, Universitas Muhammadiyah Gresik \\ ${ }^{7}$ Dosen Program Studi Budidaya Perikanan, Universitas Muhammadiyah Gresik \\ Email:zufra@umg.ac.id
}

\begin{abstract}
ABSTRAK
Peningkatan prevalensi penyebaran covid-19 terjadi di semua propinsi di Indonesia, Kelurahan kebonsari kecamatan tuban kabupaten Tuban prevalensi postif atau terkomfirmasi Covid-19 meningkat. Data covid-19 terbaru puskesmas kebonsari pada bulan mei 2021 masih terdapat yang terkomfirmasi positif covid-19. Kelurahan kebonsari sangat konsen pada pencegahan dan penurunan prevalensi covid-19 sehingga mencoba berbagai strategi, salah satunya adalah optimalisasi petugas satgas covid-19 desa dengan edukasi informal. Edukasi informal yang dilakukan meliputi menjaga jarak, memakai masker dan mencuci tangan menggunakan sabun (3M). Kegiatan edukasi dilakukan oleh satgas covid19 desa selama 14 hari dengan metode memposting poster $3 \mathrm{M}$ dan menyebar kuesioner terkait perilaku $3 \mathrm{M}$, dengan tujuan warga disiplin menggunakan prokes $3 \mathrm{M}$ dan ada perubahan dari warga yang belum disiplin prokes 3M. Optimalisasi satgas desa covid-19 melalui edukasi informal 3M didapatkan mencuci tangan dan menggunkan masker $100 \%$ dilakukan warga sedangkan menjaga jarak masih 8,7 \% belum displin. Sebaiknya Satgas Covid-19 desa melakukan pendekatan intensive dan lebih maksimal pada pendisiplinan prokes 3M sehingga upaya penurunan penyebaran pencegahan Covid-19 optimal.
\end{abstract}

Kata kunci : Kelurahan kebonsari, penurunan prevalensi, covid-19, 3M, optimalisasi satgas, edukasi informal. 


\section{DedikasiMU (Journal of Community Service)}

Volume 3, Nomor 4, Desember 2021

\section{PENDAHULUAN}

Peningkatan prevalensi penyebaran covid-19 terjadi di semua propinsi di Indonesia. Prevalensi terkomfirmasi Covid-19 mengalami peningkatan 2,90\% dalam 3 hari yaitu dari 882.418 menjadi 907.929 orang. Prevalensi kesembuhan juga meningkat 2,48\% dari 718.696 menjadi 736.460 sedangkan prevalensi meninggal meningkat $1,95 \%$. Seiring Perkembangan kesembuhan meningkat secara signifikan akan tetapi penyebaran trennya meningkat lebih besar dibandingkan dengan kesembuhan dan kematian. Hal ini menunjukkan bahwa upaya preventif sangat diperlukan dalam penurunan prevalensi penyebaran covid-19. Strategi pencegahan covid-19 dalam upaya preventif yaitu perubahan perilaku pada pendisipilinan 3M (Menjaga Jarak, Mencuci tangan dengan sabun dan Menggunakan Masker) ${ }^{4}$ dan dapat dilaksanakan dengan edukasi informal.

Jaga jarak atau physical distancing dilakukan dengan cara dilarang berdekatan atau kontak fisik dengan orang, mengatur jarak minimal 1 meter, tidak bersalaman, tidak berpelukan. Hindari penggunaan transportasi public terutama hindari jam sibuk atau berpergian. Dilarang berkumpul massal di kerumunan dan fasilitas umum termasuk tempattempat wisata. Serta membatasi melakukan kunjungan atau bersilaturahmi secara tatap muka dengan keluaraga maupun teman serta pemberian jarak dalam melaksanakan ibadah di tempat-tempat ibadah ${ }^{5}$. Cuci tangan dilakukan secara teratur dan menyeluruh menggunakan sabun dibawah air mengalir, 6 langkah dalam cuci tangan dianjurkan oleh WHO karena dapat membunuh virus corona (Covid-19) ${ }^{6}$. Pemakaian masker direkomendasikan sebagai penghalang untuk mencegah aerosol pernapasan di udara yang terhirup oleh orang lain pada saat orang dengan infeksi Covid-19 bersin, batuk, atau berbicara. Prokes $3 \mathrm{M}$ diharapkan menjadi suatu prilaku yang dapat membantu penurunan penyebaran Covid-19 melalui perubahan prilaku yang distimulasi dengan peningkatan pengetahuan terhadap pencegahan Covid-19. Pengetahuan didapatkan melalui Pendidikan formal maupun informal. Pendidikan informal dapat berupa informasi, norma maupun adat istiadat.

Kelurahan kebonsari kecamatan tuban kabupaten Tuban prevalensi postif atau terkomfirmasi Covid-19 meningkat. Data satgas Covid-19 kecamatan tuban bulan November 2019 sebanyak 137 positif, sembuh 108 dan meninggal 17 sedangkan data bulan januari 2021 sebanyak 617, sembuh 436 dan meninggal 66. Data Covid-19 terbaru puskesmas kebonsari pada bulan mei 2021 masih terdapat yang terkomfirmasi positif Covid-19 sebanyak 4 orang. Kepala kelurahan kebonsari yang konsen terhadap upaya 


\section{DedikasiMU (Journal of Community Service)}

Volume 3, Nomor 4, Desember 2021

penurunan prevalensi

penyebaran melakukan beberapa strategi salah satunya melakukan optimalisasi satgas covid-19 desa dengan edukasi informal yang dilakukan bersama dengan prodi kesehatan masyarakat Universitas Muhammadiyah Gresik. Satgas covid-19 desa merupakan garda depan pencegahan covid-19 berdasarkan tupoksinya, sehingga diperlukan analisis kinerja tuposi tersebut.

\section{METODE PELAKSANAAN}

Kegiatan penyuluhan di pimpin langsung oleh kepala kelurahan kebonsari serta dihadiri oleh bhabinkamtibmas kebonsari. Kehadiran khatibmas merupakan bentuk dukungan kegiatan tersebut.

Kegiatan edukasi informal 3M pada warga dilakukan dua (2) hari setelah kegiatan penyuluhan pada satgas Covid-19 desa dan bertepatan pada tanggal 9 April 2021. Intervensi dilakukan selama 14 hari berdasarkan masa penularan virus sehingga berakhir pada tanggal 22 April 2021. Kegiatan ini di pantau lansung oleh satgas Covid-19 desa, diketahui oleh kepala kelurahan serta bimbingan pantauan dari tim pengabmas Fakultas Kesehatan Universitas Muhammadiyah Gresik. Intervensi dilakukan selama 14 hari selain pertimbangan masa inkubasi juga faktor efektif dan efisien dana pada kelompok sasaran.

Tabel 1. Distribusi edukasi informal 3M di Kelurahan Kebonsari Kec.Tuban Kab.Tuban

\begin{tabular}{llrrr}
\hline \multicolumn{1}{c}{ Variabel } & Kategori & Pre & Post & \multirow{2}{*}{ P value } \\
\cline { 3 - 4 } & & $\mathrm{n}(\%)$ & $\mathrm{n}(\%)$ & \\
\hline Jaga Jarak & Ya & $102(88.7)$ & $105(91.3)$ & 0.549 \\
Tidak & $13(11.3)$ & $10(8.7)$ & \\
Mencuci Tangan & Ya & $115(100)$ & $115(100)$ & \\
& Tidak & - & - & \\
Memakai Masker & Ya & $115(100)$ & $115(100)$ & \\
& Tidak & - & - & \\
Pemantauan Kesehatan & Ya & $115(100)$ & $115(100)$ & \\
& Tidak & - & - \\
\hline
\end{tabular}




\section{DedikasiMU (Journal of Community Service)}

Volume 3, Nomor 4, Desember 2021

\section{HASIL DAN PEMBAHASAN}

Hasil intervensi pendidikan kesehatan dengan media WhatsApp pada variabel menjaga jarak didapatkan tidak signifikan perubahannya yaitu 0.549 ( $\mathrm{p}$ value $>\alpha$ ) artinya intervensi dengan edukasi informal dalam kurun waktu 14 hari belum bisa merubah kebiasaan. Hal ini kemungkinan bisa disebabkan karena faktor budaya dan adat istiadat ataupun ekonomi. Faktor budaya seperti berjabat tangan dan silaturahmi pada keluarga besar maupun teman sangat sulit untuk dihindari karena sudah menjadi kebiasaan warga.

Mencuci tangan $100 \%$ diterima dan dilaksanakan warga desa karena tidak bertentangan budaya karena termasuk kota santri sehingga mencuci tangan sudah menjadi kebiasaan orang berwudhu. Disetiap tempat di kelurahan kebonsari juga tersedia tempat cuci tangan dan sabun sehingga memudahkan warga melakukan cuci tangan. Memakai masker $100 \%$ dapat diterima dan dilaksanakan warga desa. Edukasi ini dapat mereka lakukan kelurahan kebonsari juga aktif berkoordinasi dengan sektor lain yaitu bhabinkamtibmas yang langsung memantau pemakaian masker di tempat -tempat umum serta adanya peraturan yang mengeluarkan sanksi denda antara Rp. 50-200 ribu sesuai kebijakan masing-masing wilayah jika tidak menggunkan masker.
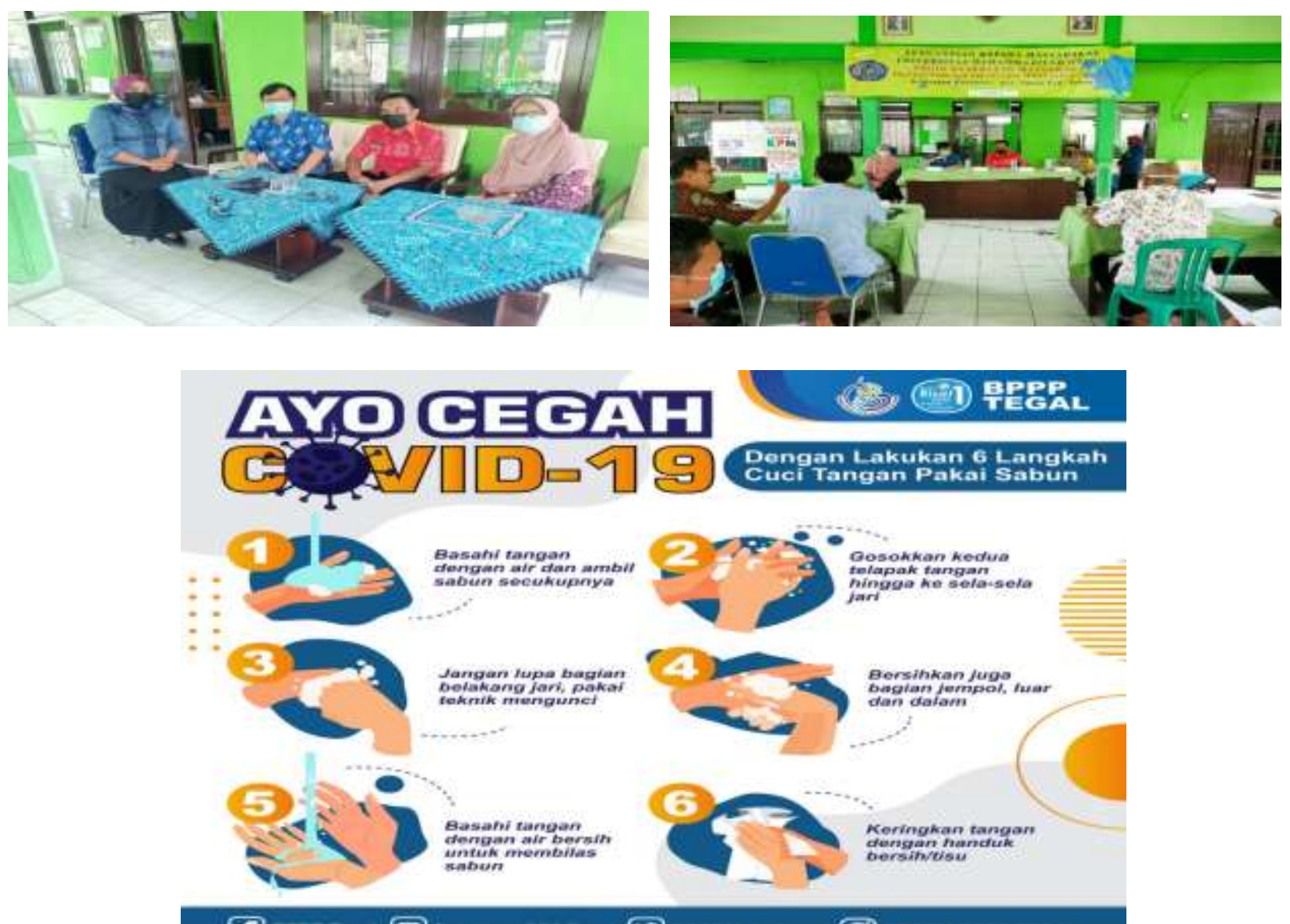

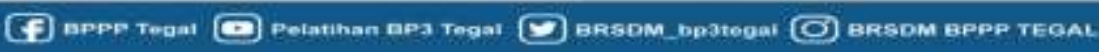




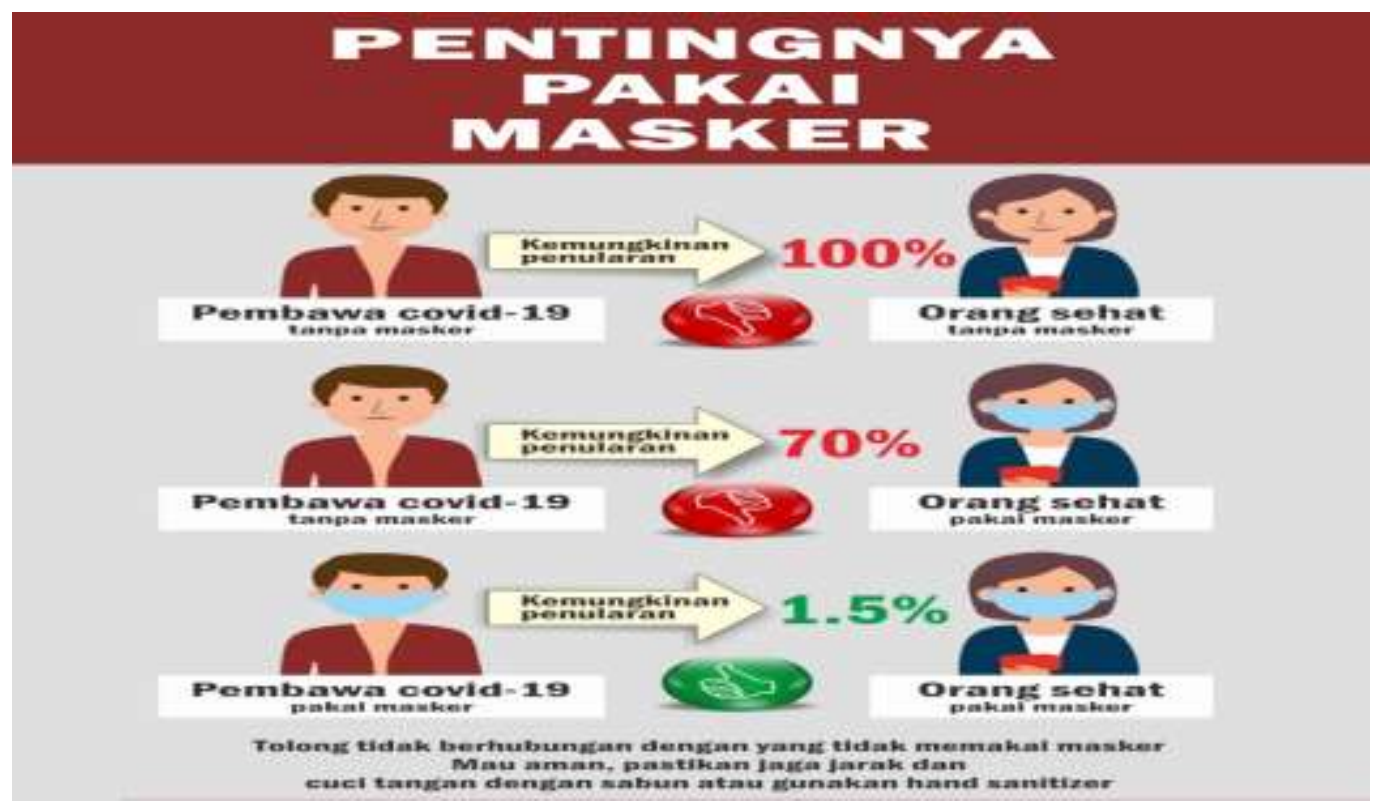

Gambar 1. Kegiatan Penyuluhan pada Satgas Covid-19 desa dan edukasi informal bentuk poster

\section{KESIMPULAN SARAN}

Hasil kegiatan pengabdian masyarakat dalam upaya penurunan prevalensi penyebaran covid-19 melalui optimalisasi satgas covid-19 desa dengan edukasi informal di kelurahan kebonsari belum optimal, seperti social distancing masih memerlukan pendekatan khusus. Sedangkan program mencuci tangan dengan sabun dan pemakaian masker dapat terlaksana warga dengan baik karena kondisi lingkungan yang mendukung seperti budaya, fasilitas tempat cuci tangan, dan koordinasi lintas sektoral dengan bhabinkamtibmas. Sebaiknya

satgas covid-19 desa melakukan pendekatan intensive dan lebih maksimal pada pendisiplinan prokes $3 \mathrm{M}$ sehingga upaya penurunan penyebaran pencegahan Covid-19 optimal.

\section{DAFTAR PUSTAKA}

Anani dan Mahmudiono. (2018). Pengaruh Pendidikan gizi terhadap Pengetahuan, sikap dan Perilaku konsumsi pangan Isovlafonpada mahasiswi Pre-menstrual Syndrome. Amerta Nutr 136-146 136 DOI :10.2473/amnt.v2i2.2018.136-146 file://C:/Users/hp/Downloads/7251-28404-2-PB\%20(1).pdf

Ardiputra S., Prawira. MR., Tasbir. (2020). Pembagian Masker Dan Sosialisasi Kebijakan Pemerintah Dalam Rangka Mendukung Pencegahan Penyebaran Covid-19 Pada Masyarakat Desa Pallis Kecamatan Balanipa. Communnity Development Journal 


\section{DedikasiMU (Journal of Community Service)}

Volume 3, Nomor 4, Desember 2021

Vol.1, No. 3 November 2020, Hal.395- 400

Firdayanti , Kautzar AM, Taherong F. (2020). Pencegahan Covid-19 Melalui Pembagian Masker Di Kelurahan Romang Polong Kabupaten Gowa. Jurnal Abdimas Kesehatan Perintis volume 2 nomor 1 tahun 2020 hal 53-57.

Kementerian Kesehatan Republik Indonesia. (2017). Peraturan menteri kesehatan Republik Indonesia Nomor 27 Tahun 2017 Tentang Pedoman PPI. Pencegahan dan Pengendalian Infeksi (PPI).

Kendari N. dan Ohorella F., (2020). Penyuluhan Physical Distancing Pada Anak Di Panti Asuhan Al Fakri. Jurnal Abdimas Kesehatan Perintis volume 2 nomor 1 tahun 2020 hal 37- 41.

Komite penanganan covid -19 dan pemulihan ekonomi Nasional. (2020). Jumlah terpapar Covid-19 di Indonesia. https://Covid-19.go.id/.

Putri.S.I. (2020). Studi Literatur: Efektivitas Penggunaan Masker Kain Dalam Pencegahan Transmisi Covid-19. Jurnal Kesehatan Manarang volume 6 nomor khusus Oktober 2020 hal. 09-17

Sinaga. L.R.V, Munthe. S.A., Bangun. H.A. (2020). Sosialisasi Perilaku Cuci Tangan Pakai Sabun Di Desa Sawo Sebagai - Bentuk Kepedulian Terhadap Masyarakat Ditengah Mewabahnya Virus Covid-19. JURNAL ABDIMAS MUTIARA Vol 1 No 2 (2020).

World Health Organization (WHO). (2020). Home care for patients with suspected novel coronavirus ( $n \mathrm{CoV}$ ) infection presenting with mild symptoms and management of contacts. https://www.who.int/internal-publications-detail/home-care-for-patientswithsuspected-novel-coronavirus-(nCoV)-infection-presenting-with-mildsymptoms-andmanagement-of-contacts. 